\title{
Character Association and Path Coefficient Analysis for Yield and Its Related Traits in Ethiopian Coffee (Coffea arabica L.) Accessions
}

\author{
Getachew WeldeMichael* \\ Jimma Agricultural Research Center, P.O. Box, 192, Jimma, Ethiopia
}

*Corresponding Author: Getachew WeldeMichael, Jimma Agricultural Research Center, P.O. Box, 192, Jimma, Ethiopia

\begin{abstract}
Coffee is the world's most widely traded tropical agricultural commodity next to oil and is the back bone to the Ethiopian economy. The associations between yield and its components offer important information for plant breeders. Hence, this experiment was conducted at Agaro research station, southwest Ethiopia, to determine the extent of correlations among yield and its related traits of 49 coffee accessions and to assess the direct and indirect effects of these traits on coffee yield. The experiment was conducted in simple lattice design with two replications. Data on yield and its components were recorded and analysis of variance, correlation and path coefficient analysis were performed. The result revealed that significant $(P<0.05)$ differences among the coffee accessions for all traits except for percent of bearing primary branches, leaf area, bean thickness and rust incidence. All traits showed non significant correlation with coffee yield at phenotypic level. However, morphological traits, namely, average inter node length on stem, stem diameter, angle of primary branches, fruit length, fruit width and fruit thickness exhibited positive and significant $(P<0.05)$ correlation with coffee yield at genotypic level and are important components to improve it. Besides, path coefficient analysis showed that average-inter nodes length on main stem, stem diameter, angle of primary branches, fruit length and fruit thickness having positive direct effects, exhibited positive significant genotypic correlation with coffee yield and these traits are important for direct selection to improve coffee yield. On the other hand, fruit width showed negative direct effect but positive and significant genotypic correlation with coffee yield and can be used for indirect selection. In conclusion, average inter node length of main stem, stem diameter, angle of primary branches, fruit length, fruit thickness and fruit width can be used as direct and indirect selection criteria to improve coffee yield.
\end{abstract}

Keywords: Accessions, Agaro, Correlation, Direct effect and Stem diameter

\section{INTRODUCTION}

Coffee is the world's most widely traded tropical agricultural commodity (ICO, 2011), next to oil (Prakash et al., 2002). It accounts for nearly half of the total exports of tropical products (FAO, 2009). In many producing countries, besides contributing a tremendous amount to the foreign exchange currency, it serves as a means of livelihood for millions of people (Steiger et al., 2002). It contributes $25-30 \%$ of the Ethiopian foreign currency earnings ((FDRE MOT, 2012) and supports the livelihood of more than 20 million people in the country (Gole and Senbeta, 2008). However, the productivity is very low as compared to other producing countries.

The coffee yield is a complex character that can be determined by several components which reflect positive or negative effects upon this trait. The importance of using component selection criteria for high yielding genotypes was noted by Leroy et al. (1997) and Montagnon et al. (2001). Thus, knowledge of the relationships between yield and its components is important for selecting or improving two or more variables contributing to yield. It is also important to examine the contribution of each of the various components in order to attract the attention to the one which has the greatest influence on coffee yield.

Simple correlation analysis indicates the degree of association between traits, but it can't provide reasons of association. Therefore, simple correlation coefficients are not always effective in determining the real relationships among traits. However, path coefficient analysis allows a more precise elucidation of the pattern of interaction of other known factors. It permits identification of 
direct and indirect causes of association and measures the relative importance of each character (Ariyo et al., 1987). Therefore, it is desirable to know the direct and indirect effect of yield components on coffee yield as these traits could be useful indicators in breeding programs to select coffee genotype for higher yield.

Few researchers reported the association between yield and its components. For example, Olika et al. (2011) have reported significant and positive genotypic correlations of coffee yield with plant height, canopy diameter, percentage bearing primary branches, fruit length, hundred bean weight, leaf length, bean width and height up to first primary branches at genotypic level, but no significant correlation between yield and all its components at phenotypic level. Moreover, Gizachew and Hussein (2017) have reported that hundred green bean weight, stem diameter, canopy diameter, average length of primary branches, percent of bearing primary branches and leaf length had positive and significant correlation with coffee yield and they have also reported that among the different yield contributing traits, plant height, leaf length, leaf width, hundred green bean weight, percentage of bearing primary branches, stem diameter, average length of primary branches and coffee berry disease infestation influenced coffee yield directly and indirectly.

Despite information on path coefficient analysis in coffee is scanty, Seyoum (2003) reported that angle of primary branches and length of the longest primary branches exerted the highest direct effect on coffee yield. Besides, Ermias (2005) has also reported that number of main stem node followed by plant height and number of berry per node had the highest direct effect on coffee yield. Similarly, Lemi et al. (2017) have reported that plant height, canopy diameter and length of first primary branch had the highest positive direct effect on coffee yield and suggested that selection using these characters would be helpful to improve coffee yield in Arabica coffee.

However, phenotypic correlation, genotypic correlation and path coefficient analysis were not conducted for yield and its related traits on coffee accessions collected from Gomma Woreda. Thus, the objectives of this study were to estimate the phenotypic and genotypic correlations among coffee yield and its related traits and to see the direct and indirect effects of these traits on coffee yield.

\section{Materials And Methods}

\subsection{Description of the Study Area}

The experiment was conducted at Agaro Station of the Jimma Agricultural Research Center, which is $45 \mathrm{~km}$ far from Jimma and $397 \mathrm{~km}$ from Addis Ababa. Agaro is located at latitudinal gradient of $7^{0} 50^{\prime} 35^{\prime \prime}-7^{0} 51^{\prime} 00^{\prime}$ ' $\mathrm{N}$ and longitudinal gradient of $36^{\circ} 35^{\prime} 30^{\prime \prime} \mathrm{E}$ with an altitude of $1650 \mathrm{~m}$ above sea level. The mean annual rainfall of the area is $1616 \mathrm{~mm}$ with an average maximum and minimum air temperatures of $28.4^{\circ} \mathrm{C}$ and $12.4^{\circ} \mathrm{C}$, respectively (Elias, 2005). The major soil type is Mollic Nit sols with $\mathrm{pH}$ of 6.2 , organic matter $7.07 \%$, nitrogen $0.42 \%$, phosphorus $11.9 \mathrm{ppm}$, CEC $39.40 \mathrm{cmol}(+) / \mathrm{kg}$ (Zebene and Wondwosen, 2008).

\subsection{Study Materials, Design and Management}

Forty seven C. arabica L. germplasm accessions, which have been collected from the Gomma Woreda of Jimma Zone and two standard checks, were used for this study. The experiment was superimposed during the 2012 cropping season on six years old coffee trees, which were planted in July, 2006 and grown under uniform coffee shade trees (Sesbania sesban) conditions. The experiment was laid out in a $7 \times 7$ simple lattice design with two replications. Each plot was comprised of four coffee trees. Spacing between trees and plots was two meter and spacing between replications was 3 meter. All improved agronomic practices were applied uniformly according to the recommendations (Endale et al., 2008).

\subsection{Data Collected}

Data on 26 quantitative characters, namely: Height up to first primary branch $(\mathrm{cm})$, total plant height $(\mathrm{cm})$, number of main stem nodes (no), average inter node length of main stem $(\mathrm{cm})$, main stem diameter $(\mathrm{cm})$, angle of primary branches( $\mathrm{deg}$ ), number of primary branches (no), average length of primary branches $(\mathrm{cm})$, number of nodes of primary branches (no), average inter node length of primary branches $(\mathrm{cm})$, percentage of bearing primary branches $(\%)$, number of secondary branches (no), canopy diameter $(\mathrm{cm})$, leaf length $(\mathrm{cm})$, leaf width $(\mathrm{cm})$, leaf area $(\mathrm{cm} 2)$, fruit length $(\mathrm{mm})$, fruit 
width $(\mathrm{mm})$, fruit thickness $(\mathrm{mm})$, bean length $(\mathrm{mm})$, bean width $(\mathrm{mm})$, bean thickness $(\mathrm{mm})$, hundred bean weight $(\mathrm{gm})$, yield per tree $(\mathrm{kg})$, coffee berry disease $(\%)$ and rust incidence $(\%)$, were collected from each accession using the standard procedures ( IPGRI, 1996)

\subsection{Data Analysis}

Data of quantitative characters were subjected to analysis of variance (ANOVA) using SAS version 9.2 (SAS, 2008) to examine the presence of statistically significant differences among accessions. Twenty two characters, which showed significant differences among the accessions, were used for correlation and path coefficient analysis. The phenotypic and genotypic correlation coefficients were estimated using the formula suggested by Johnson et al. (1955) and Singh and Chaudhury (1987).

$$
\text { rp }=\text { Pcovxy } / \sqrt{ }(\text { Vpx. Vpy) }
$$

Where, $r p=$ Phenotypic correlation coefficient

Pcovxy $=$ Phenotypic covariance between traits $\mathrm{x}$ and $\mathrm{y}$

$\mathrm{Vpx}=$ Phenotypic variance of trait $\mathrm{x}$

Vpy $=$ Phenotypic variance of trait $y$

$\mathrm{rg}=\mathrm{Gcovxy} / \sqrt{ }($ Vgx. Vgy)

Where $\mathrm{rg}=$ Genotypic correlation coefficient

Gcovxy $=$ Genotypic covariance between traits $\mathrm{x}$ and $\mathrm{y}$

$\operatorname{Vgx}=$ Genotypic variance of trait $\mathrm{x}$

$\mathrm{Vgy}=$ Genotypic variance of trait $\mathrm{y}$

The coefficients of correlation were tested using " $\mathrm{r}$ " tabulated value at $\mathrm{n}-2$ degree of freedom, at $5 \%$ and $1 \%$ probability level, where $\mathrm{n}$ is the number of accessions

Path coefficient analysis was estimated for morphological traits following the method described by Dewey and Lu (1959).

rij $=$ Pij + Srikpkj

The residual effect was determined as described in Dewey and Lu (1959).

$\sqrt{ } \mathbf{1}-\mathbf{R}^{\mathbf{2}}$

Where: $\mathrm{R}^{2}=\Sigma$ pij. rij

pij $=$ Component of direct effects of the independent character (i) on dependent character (j) as measured by the path coefficient.

rij = Mutual association between the independent character (i) and dependent character (j) as measured by the correlation coefficient.

\section{RESULTS AND DISCUSSION}

\subsection{Phenotypic and Genotypic Correlations of Coffee bean Yield with other Quantitative Traits}

\subsubsection{Phenotypic Correlation Of coffee bean yield with other Quantitative Traits}

Generally, the phenotypic correlation coefficients were lower than the genotypic values, indicating that the influence of environmental factors is lower than the inherent genetic effects (Walyaro and Van der Vossen, 1979). According to Falconer (1989), significant correlation coefficients among various characters may occur from pleotropic effects of genes or from linkage effects. Generally, negative correlation between two traits implies selection for improving one trait will likely cause decrease in the other trait, whereas for positive correlation, simultaneous improvements of both traits could be achieved (Rangaswamy, 1995). Associations of yield with other traits at phenotypic level are presented in Table 1. At phenotypic level, coffee yield per plant showed positive but non significant correlations with height up to first primary branch, average inter node length of main stem, angle of primary 
branches, leaf length and width, fruit length and thickness, bean length and width, and hundred bean weight. However, coffee yield showed negative and non significant correlations with all other traits.

This is in agreement with the findings of Olika et al., (2011) who have reported no significant phenotypic correlation of all morphological characters with coffee yield. Similarly, Seyoum (2003) has reported that yield exhibited significant positive association only with leaf area at phenotypic level. However, in contrast to the current findings, Ermias (2005) has reported that average yield had significant and positive associations with plant height, girth, number of primary branches, canopy diameter and average length of primary branch. Gizachew and Hussein (2017) have also reported that average yield exhibited positive and significant correlations with hundred green bean weight, stem diameter, angle of primary branch, canopy diameter, average length of primary branches, percent of bearing primary branches, leaf length and bean width. The variation might have been attributed to the differences in the study materials and the environments on which the experiments were conducted.

Table1. Phenotypic corrélation coefficients of the 22 characters in 49 coffee (Coffea arabica.L) germplasm accessions grown at Agaro (2011/12)

\begin{tabular}{|c|c|c|c|c|c|c|c|c|c|c|c|c|}
\hline Character & HUP & TPH & NNMS & AILMS & SD & APB & NPB & ALPB & NNPB & AILPB & NSB & CD \\
\hline HUP & 1.000 & 0.214 & 0.041 & 0.027 & $0.416^{* *}$ & 0.156 & -0.116 & -0.080 & 0.220 & 0.187 & 0.109 & 0.013 \\
\hline TPH & & 1.000 & $0.550^{* *}$ & $0.341^{* *}$ & $0.461^{* *}$ & $0.286^{*}$ & $0.563^{* * *}$ & $0.354^{* *}$ & 0.041 & $0.258^{* *}$ & 0.241 & $0.323^{*}$ \\
\hline NNMS & & & 1.000 & $-0.528^{* *}$ & 0.189 & -0.003 & $0.769^{* *}$ & -0.059 & 0.198 & $-0.291^{*}$ & $0.274^{*}$ & 0.079 \\
\hline AILMS & & & 1.000 & 0.181 & $0.276^{*}$ & $-0.315^{*}$ & $0.454^{* *}$ & -0.153 & $0.579^{* *}$ & -0.064 & 0.239 \\
\hline SD & & & & 1.000 & 0.198 & 0.214 & 0.114 & -0.067 & 0.179 & 0.207 & $0.378^{* *}$ \\
\hline APB & & & & & & 1.000 & -0.096 & 0.143 & -0.080 & 0.214 & -0.005 & 0.011 \\
\hline NPB & & & & & & 1.000 & 0.119 & $0.328^{*}$ & $-0.294^{*}$ & $0.450^{* * *}$ & 0.211 \\
\hline ALPB & & & & & & & 1.000 & $0.534^{* *}$ & $0.262^{*}$ & 0.070 & $0.579^{* *}$ \\
\hline NNPB & & & & & & & & 1.000 & $-0.672^{* *}$ & 0.009 & $0.351^{* *}$ \\
\hline AILPB & & & & & & & & & & 1.000 & 0.035 & 0.111 \\
\hline NSB & & & & & & & & & & 1.000 & 0.010 \\
\hline CD & & & & & & & & & & & 1.000 \\
\hline
\end{tabular}

Table1. Continued

\begin{tabular}{|c|c|c|c|c|c|c|c|c|c|c|}
\hline characters & LL & LW & FL & FW & FT & BL & BW & HBW & CBD & Yd/tr \\
\hline HUP & 0.095 & $0.249^{*}$ & 0.141 & 0.086 & 0.199 & 0.034 & 0.099 & 0.178 & -0.048 & 0.017 \\
\hline TPH & 0.131 & $0.252^{*}$ & 0.215 & 0.091 & 0.124 & -0.046 & 0.007 & 0.137 & 0.045 & -0.049 \\
\hline NNMS & $-0.302^{*}$ & -0.218 & -0.189 & -0.148 & -0.102 & -0.151 & -0.213 & -0.239 & $0.282^{*}$ & -0.044 \\
\hline AILMS & $0.518^{* *}$ & $0.522^{* *}$ & $0.390^{* *}$ & 0.234 & 0.194 & 0.097 & $0.257^{*}$ & $0.401^{* *}$ & $-0.278^{*}$ & 0.038 \\
\hline SD & 0.191 & 0.033 & 0.156 & 0.207 & 0.170 & 0.028 & 0.083 & 0.172 & 0.165 & -0.137 \\
\hline APB & $0.329^{*}$ & 0.207 & 0.147 & 0.032 & 0.009 & -0.079 & -0.047 & -0.033 & 0.050 & 0.012 \\
\hline NPB & $-0.265^{*}$ & -0.206 & -0.173 & -0.198 & -0.111 & -0.156 & -0.225 & -0.219 & $0.275^{*}$ & -0.160 \\
\hline ALPB & $0.356^{* *}$ & $0.397^{* *}$ & 0.228 & 0.087 & -0.073 & -0.046 & -0.008 & 0.159 & -0.082 & -0.148 \\
\hline NNPB & -0.172 & -0.075 & -0.147 & -0.142 & $-0.249^{* *}$ & -0.178 & -0.146 & -0.221 & 0.163 & -0.055 \\
\hline AILPB & $0.512^{* *}$ & $0.437^{* *}$ & $0.359^{* *}$ & 0.224 & 0.202 & 0.150 & 0.155 & $0.380^{* * *}$ & $-0.253^{*}$ & -0.053 \\
\hline NSB & -0.066 & -0.018 & -0.042 & -0.207 & 0.045 & 0.041 & -0.045 & -0.004 & -0.094 & -0.001 \\
\hline CD & 0.026 & 0.059 & -0.032 & 0.006 & -0.082 & -0.071 & -0.127 & -0.017 & 0.025 & -0.201 \\
\hline LL & 1.000 & $0.683^{* *}$ & $0.290^{*}$ & $0.347^{* *}$ & 0.105 & 0.019 & 0.148 & $0.344^{* * *}$ & -0.220 & 0.047 \\
\hline LW & & 1.000 & $0.276^{*}$ & 0.234 & 0.144 & -0.008 & 0.235 & $0.317^{*}$ & -0.236 & 0.073 \\
\hline FL & & & 1.000 & $0.478^{* *}$ & $0.403^{* *}$ & $0.460^{* *}$ & $0.339^{* *}$ & $0.521^{* *}$ & -0.202 & 0.142 \\
\hline FW & & & & 1.000 & $0.611^{* *}$ & 0.104 & $0.358^{* *}$ & $0.487^{* *}$ & -0.141 & -0.017 \\
\hline FT & & & & & 1.000 & 0.134 & $0.415^{* *}$ & $0.410^{* *}$ & -0.186 & 0.065 \\
\hline BL & & & & & & 1.000 & $0.506^{* *}$ & $0.656^{* *}$ & -0.031 & 0.029 \\
\hline BW & & & & & & & 1.000 & $0.740^{* *}$ & -0.062 & 0.119 \\
\hline HBW & & & & & & & & 1.000 & -0.237 & 0.084 \\
\hline CBD & & & & & & & & & 1.000 & -0.137 \\
\hline
\end{tabular}

$* *=$ highly significant at $(P<0.01)=0.34, *=$ significant at $P<0.05=0.245$, HUP= height up to first primary branch. TPH= total plant height, NMSN= number of main stem nodes, AILMS = average inter node length of main stem, $S D=$ stem diameter, APB = Angle of primary branches, $N P B=$ number of primary branches, $A L P B=$ Average length of primary branches, NNPB= number of nodes of primary branches, $A I L P B=$ average inter node length of primary branches, NSB=Number of secondary branches, $C D=$ canopy diameter, LL= leaf length, LW= leaf width, $F L=$ fruit length, $F W=$ fruit width, FT= fruit thickness, $B L=$ bean length, BW= bean width, HBW= hundred bean weights, $C B D=$ coffee berry disease, $Y D /$ tr $=$ yield per tree. 


\subsubsection{Genotypic Correlation of coffee bean yield with other Quantitative Traits}

Associations of yield with other traits at genotypic level are presented in Table 2. Coffee yield per tree had positive and significant associations with average inter node length of stem, stem diameter, angle of primary branches, fruit length, fruit width and fruit thickness at genotypic level. On the other hand, number of primary branches, average length of primary branches and CBD reaction showed negative and significant correlation with yield per plant. However, coffee yield had non significant relationships with the rest of the characters. In agreement with the current findings, Ermias (2005) has reported significant and positive associations of coffee yield with plant height stem diameter and fruit length. However, the current findings is in contrast with the same author who has reported positive and significant associations of coffee yield with number of main stem nodes and canopy diameter. The contradictory result might have been due to differences in the age of the test materials and environments. Olika et al. (2011) have also reported significant and positive genotypic correlations of coffee yield per tree with plant height, canopy diameter, and percentage bearing primary branches, fruit length, hundred bean weight, leaf length, bean width and height up to first primary branches.

Generally, in those traits in which coffee yield showed positive and significant correlations, there were interactions in which a gene conditioning an increase in one trait will also influence coffee yield provided that other conditions are kept constant. Thus, growth characters that exhibited positive and significant correlations with yield, namely, average inter node length of main stem, stem diameter, angle of primary branches, fruit length, width and thickness are important yield components to improve coffee yield. Nevertheless, those traits that showed negative and significant correlation with coffee yield such as number and length of primary branches, independent selection should be carried out as selection for such traits may not result in improvement of coffee yield.

\subsection{Phenotypic and Genotypic Correlation among Other Traits}

\subsubsection{Phenotypic Correlation among other Traits}

Coffee berry disease severity exhibited positive and significant correlations with number of main stem nodes and primary branches. Conversely, CBD showed negative and significant correlations with average internode length of stem and primary branches. On the other hand, this trait had non significant correlations with all other traits. The non significant phenotypic correlations observed between this trait and most of the traits in this study are in agreement with the findings of Ermias (2005).

Total plant height exhibited positive correlations with most of the traits but it had positive and significant correlations only with number of main stem nodes, average inter node length of main stem and primary branches, stem diameter, angle of primary branches, number of primary branches, average length of primary branches, canopy diameter and leaf width. However, it showed positive and non significant correlations with the rest of the characters. Stem diameter exhibited positive and significant correlation only with canopy diameter. Nevertheless, it showed very weak positive correlations with most of the traits at phenotypic level. Average inter node length of main stem displayed positive and significant correlations with angle of primary branches, average length of primary branches, average inter node length of primary branches, leaf length and width, fruit length, bean width and hundred bean weight but It had non-significant correlations with most of the other traits. The positive phenotypic correlations of plant height, stem diameter and average inter node length of main stem with most of the traits observed in the present study is in agreement with the findings of Cilas et al. (1998).

Number of primary branches had positive and significant correlations with number of nodes of primary branches and number of secondary branches. This trait manifested positive but no significant correlations with average length of primary branches and canopy diameter. On the other hand, it showed negative correlations with other traits but it exhibited negative and significant correlations only with average inter node length of primary branches and leaf length (Table 1). Average length of primary branches exhibited positive and significant correlations with number of nodes on primary branches, average inter node length of primary branches, canopy diameter, leaf length and leaf width. However, this trait exhibited non significant correlations with other traits.

Number of nodes of primary branches had positive and significant association with canopy diameter but it had negative and significant associations with average inter node length of primary branches and 
fruit thickness. Average inter-node length of primary branches exhibited positive and significant associations only with leaf length, width, fruit length and hundred bean weights, while It had nonsignificant associations with other traits. Both number of secondary branches and canopy diameter exhibited non significant associations with all morphological traits. Leaf length displayed positive and significant associations with leaf width, fruit length, width and hundred bean weights. However, this trait showed no significant associations with other traits. Leaf width also showed positive and significant associations with fruit length and hundred bean weight.

Fruit length had positive and significant associations with fruit width, fruit thickness, bean length, bean width and hundred bean weights. Fruit width showed positive and significant associations with fruit thickness, bean width and hundred bean weight. Both fruit thickness and bean length displayed positive and significant associations with bean width and hundred bean weight. Bean width also showed positive and significant association with hundred bean weight.

Table2. Genotypic corrélation coefficients of the 22 characters in 49 coffee (Coffea arabica.L) germplasm accessions grown at Agaro (2011/12)

\begin{tabular}{|c|c|c|c|c|c|c|c|c|c|c|c|c|}
\hline character & HUP & TPH & NNMS & AILMS & SD & APB & NPB & ALPB & NNPB & AILPB & NSB & CD \\
\hline HUP & 1.000 & $0.431^{* *}$ & 0.065 & $0.297^{*}$ & $0.398^{* *}$ & $0.532^{* *}$ & $-0.283^{*}$ & 0.002 & -0.179 & 0.219 & 0.136 & 0.051 \\
\hline TPH & & 1.000 & $0.559^{* *}$ & $0.659^{* *}$ & $0.563^{* *}$ & $0.614^{* *}$ & $0.334^{*}$ & $0.657^{* *}$ & -0.035 & $0.460^{* *}$ & $0.621^{* *}$ & $0.476^{* *}$ \\
\hline NNMS & & & 1.000 & $-0.261^{*}$ & $0.272^{*}$ & $0.405^{* * *}$ & $0.763^{* *}$ & $0.447^{* *}$ & $0.448^{* *}$ & -0.244 & $0.577^{* * *}$ & $0.438^{* * *}$ \\
\hline AILMS & & & 1.000 & $0.452^{* *}$ & $0.382^{* *}$ & -0.197 & $0.336^{*}$ & $-0.428^{* *}$ & $0.719^{* * *}$ & 0.174 & 0.167 \\
\hline SD & & & & 1.000 & $0.408^{* *}$ & 0.060 & $0.373^{* *}$ & -0.010 & $0.269^{*}$ & $0.498^{* *}$ & $0.323^{*}$ \\
\hline APB & & & & & & 1.000 & 0.114 & -0.197 & $-0.514^{* * *}$ & $0.446^{* *}$ & $0.305^{*}$ & $-0.352^{* *}$ \\
\hline NPB & & & & & & 1.000 & $0.570^{* *}$ & $0.613^{* * *}$ & $-0.390^{* *}$ & $0.865^{* * *}$ & $0.501^{* * *}$ \\
\hline ALPB & & & & & & & 1.000 & $0.499^{* * *}$ & 0.061 & $0.385^{* *}$ & $0.997^{* *}$ \\
\hline NNPB & & & & & & & & & 1.000 & $-0.833^{* *}$ & 0.168 & $0.644^{* *}$ \\
\hline AILPB & & & & & & & & & & 1.000 & -0.002 & 0.023 \\
\hline NSB & & & & & & & & & & 1.000 & $0.270^{*}$ \\
\hline
\end{tabular}

Table2. Continued ........

\begin{tabular}{|c|c|c|c|c|c|c|c|c|c|c|}
\hline Character & LL & LW & FL & FW & FT & BL & BW & HBW & CBD & $\mathrm{Yd} / \mathrm{tr}$ \\
\hline HUB & $0.272 *$ & $0.540 * *$ & 0.216 & 0.126 & 0.705 ** & 0.048 & 0.154 & $0.284 *$ & -0.099 & -0.074 \\
\hline TPH & $0.401 * *$ & $0.534 * *$ & $0.327 *$ & -0.000 & 0.168 & 0.002 & 0.099 & $0.249^{*}$ & -0.419 ** & 0.061 \\
\hline NNMS & $-0.315^{*}$ & $-0.263^{*}$ & -0.212 & $-0.997 * *$ & $-0.998 * *$ & $-0.317^{*}$ & $-0.550 * *$ & $-0.471 * *$ & 0.619 ** & -0.193 \\
\hline AILMS & $0.733 * *$ & $0.818^{* * *}$ & $0.563 * *$ & $0.980 * *$ & $0.970 * *$ & $0.260 *$ & $0.671 * *$ & $0.733 * *$ & -0.939 ** & $0.349 * *$ \\
\hline SD & $0.652 * *$ & \begin{tabular}{|l|l|}
$0.297 *$ \\
\end{tabular} & 0.120 & \begin{tabular}{|l|}
-0.074 \\
\end{tabular} & \begin{tabular}{|l|}
0.199 \\
\end{tabular} & 0.088 & $0.263^{*}$ & $0.314^{*}$ & -0.011 & $0.245^{*}$ \\
\hline APB & $0.479 * *$ & $0.299 *$ & 0.097 & -0.213 & 0.012 & -0.091 & -0.014 & 0.035 & $0.312^{*}$ & $0.245^{*}$ \\
\hline NPB & -0.228 & -0.221 & -0.227 & $-0.855 * *$ & $-0.969 * *$ & -0.119 & $-0.485^{* *}$ & $-0.351^{* *}$ & 0.194 & $-0.323^{*}$ \\
\hline ALPB & -0.063 & 0.137 & 0.156 & $0.268 *$ & $0.254 *$ & 0.014 & \begin{tabular}{|l|}
0.028 \\
\end{tabular} & 0.206 & $-0.974 * *$ & $-0.379 * *$ \\
\hline NNPB & $-0.506 * *$ & $-0.352 * *$ & $-0.391 * *$ & $-0.573 * *$ & -0.616 ** & -0.128 & $-0.321 *$ & -0.234 & 0.210 & -0.217 \\
\hline AILPB & $0.533 * *$ & $0.505 * *$ & $0.564 * *$ & $0.856 * *$ & $0.865 * *$ & 0.140 & $0.366 * *$ & $0.398 * *$ & $-0.896 * *$ & -0.003 \\
\hline NSB & $-0.273^{*}$ & -0.058 & 0.128 & $-0.441 * *$ & $-0.324^{*}$ & 0.179 & $-0.256^{*}$ & 0.004 & $-0.440^{* * *}$ & -0.125 \\
\hline CD & $0.245 *$ & $0.374 * *$ & 0.022 & 0.189 & $0.369 * *$ & -0.139 & -0.070 & -0.002 & $-0.518^{* * *}$ & -0.132 \\
\hline LL & 1.000 & $0.507 * *$ & $0.274 *$ & $0.972 * *$ & $0.518 * *$ & 0.114 & $0.322 *$ & $0.442 * *$ & $-0.648 * *$ & -0.209 \\
\hline LW & & 1.000 & 0.196 & $0.570 * *$ & $0.575 * *$ & 0.056 & $0.467 * *$ & $0.460 * *$ & $-0.953 * *$ & 0.059 \\
\hline FL & & & 1.000 & 0.126 & $0.435 * *$ & $0.990 * *$ & $0.672 * *$ & 0.790 ** & -0.797 ** & $0.440 * *$ \\
\hline FW & & & & 1.000 & $0.580 * *$ & $0.575 * *$ & $0.859 * *$ & $0.979 * *$ & -0.960 ** & $0.253 *$ \\
\hline FT & & & & & 1.000 & $0.952 * *$ & $0.998 * *$ & 0.970 ** & -0.787 *** & $0.531 * *$ \\
\hline $\mathrm{BL}$ & & & & & & 1.000 & 0.628 ** & $0.756 * *$ & $-0.406^{* * *}$ & 0.075 \\
\hline BW & & & & & & & 1.000 & $0.898 * *$ & $-0.558^{* * *}$ & 0.138 \\
\hline HBW & & & & & & & & 1.000 & -0.543 ** & 0.106 \\
\hline CBD & & & & & & & & & 1.000 & $-0.265^{*}$ \\
\hline
\end{tabular}

$* *=$ highly significant at $(P<0.01)=0.34, *=$ significant at $P<0.05=0.245$, HUP= height up to first primary branch. TPH= total plant height, $\quad N M S N=$ number of main stem nodes, AILMS = average inter node length of main stem, $S D=$ stem diameter, $A P B=$ Angle of primary branches, $N P B=$ number of primary branches, $A L P B=$ Average length of primary branches, $N N P B=$ number of nodes of primary branches, AILPB = average inter node length of primary branches, $N S B=$ Number of secondary branches, $C D=$ canopy diameter, $L L=$ leaf length, $L W=$ leaf width, $F L=$ fruit length, $F W=$ fruit width, $F T=$ fruit thickness, $B L=$ bean length, $B W=$ bean width, $H B W=$ hundred bean weights, $C B D=$ coffee berry disease, $Y D /$ tr = yield per tree. 


\subsubsection{Genotypic Correlation among other Traits}

Genotypic correlation coefficients among other quantitative characters are given in Table 2. Generally, the magnitude of genotypic correlation coefficient was higher in magnitude than its corresponding phenotypic correlation.

CBD severity showed significant and positive correlations with both number of nodes of main stem and angle of primary branches. The positive and significant correlations between CBD severity and these traits suggest that increase in these two traits will result in increasing CBD severity. So selection for number of nodes of main stem and angle of primary branches could seriously affect the improvement of CBD resistance. However, It had negative and significant correlations with plant height, average inter node length of main stem, average length of primary branches, average inter node length of primary branches, number of secondary branches, canopy diameter, leaf length and width, fruit length, width and thickness, bean length, bean width and hundred bean weight. The negative and significant correlations of these traits with CBD severity enable the breeder for simultaneous improvement of the coffee berry disease resistance level and these traits.

Plant height showed positive and significant correlations with most of the traits namely, number of main stem nodes, average inter node length of main stem, stem diameter, angle of primary branches, number of primary branches, average length of primary branches, average inter node length of primary branches, number of secondary branches, canopy diameter, leaf length and width, fruit length and hundred bean weight. On the other hand, It had non significant associations with the rest of the characters. The positive and significant genotypic correlations of plant height with most of morphological traits observed in the current study are supported by earlier investigators (Seyoum, 2003; Ermias, 2005; Olika et al., 2011).

Number of nodes of main stem showed positive and significant correlations with most of the traits namely, stem diameter, angle of primary branches, number of primary branches, average length of primary branches, number of nodes of primary branches, number of secondary branches, canopy diameter. But it had negative and significant correlations with average inter node length of main stem, leaf length and width, fruit width, thickness, bean length, width and hundred bean weights.

Average inter node length of main stem had positive and significant correlations with stem diameter, angle of primary branches, average length of primary branches, average inter node length of primary branches, leaf length and width, fruit length, width and thickness, bean length and width and hundred seed weight. This implies that accessions with longer inter nodes of main stem have taller height, greater stem diameter and angle of primary branches, longer primary branches, longer inter nodes on primary branches, larger leaf, fruit and bean size and heavier bean weight and vise versa. Thus, simultaneous selection for average internodes length of main stem and any one of the above traits would be essential for improvement of the characters. The positive and significant correlations of average inter node length of stem with most of the growth characters is in agreement with the work of Olika et al. (2011). Conversely, this trait had negative and significant correlations with number of nodes on main stem and primary branches, suggesting that number of nodes influenced average inter node length, as the number of nodes increases, the corresponding inter node length will be smaller while other traits kept constant. This finding is consistent with the findings of Seyoum (2003) and Olika et al. (2011)

Stem diameter had positive and significant correlations with angle of primary branches, average length of primary branches, average inter node length of primary branches, number of secondary branches, canopy diameter, leaf length and width, bean width and hundred bean weights, while it had no significant associations with the rest of the traits. This finding partly agrees with the findings of Ermias (2005).

Number of primary branches exhibited positive and significant correlations with average length of primary branches, number of nodes of primary branches, number of secondary branches and canopy diameter. On the other hand, this trait showed negative and significant associations with average inter node length of primary branches, fruit width and thickness, bean width and hundred seed weight. The current findings partly agree with the findings of Olika et al. (2011) who reported positive and significant correlations of number of primary branches with length of primary branches and number of secondary branches; negative and significant genotypic correlations of number of primary branches with plant height, average inter nodes length of stem and leaf width. 
Average length of primary branches exhibited positive and significant correlations with number of nodes of primary branches, number of secondary branches, canopy diameter, fruit width and fruit thickness. On the other hand, it had no significant associations with the rest of the characters. Olika et al. (2011) have also reported that length of primary branches had positive and strong associations with plant height, average inter nodes length of stem, number of primary branches, leaf length and width, while negative and non significant associations of this trait with bean width, fruit width and thickness, angle of primary braches, number of primary and number of secondary branches.

Number of nodes of primary branches displayed positive and significant association only with canopy diameter. However, it had negative and significant associations with average inter node length of primary branches, leaf length and width, fruit length, width and thickness and bean width and it had no significant associations with other traits.

Average inter node length of primary branches had positive and significant associations with leaf length, leaf width, fruit length, width and thickness, bean width and hundred seed weight but it had no significant associations with other traits. Number of secondary branches had negative and significant associations with leaf length, fruit width, thickness and bean width but it had no significant associations with other traits. Canopy diameter had positive and significant associations with leaf length and width and fruit thickness.

Leaf length had positive and significant associations with leaf width, fruit length, width and thickness, bean width and hundred bean weights. Leaf width showed positive and significant associations with fruit width, thickness, bean width and hundred seed weight. Fruit length had positive and significant associations with fruit thickness, bean length, width and hundred bean weights. Fruit width also showed positive and significant associations with fruit thickness, bean length, width and hundred bean weights. Fruit thickness had positive and significant associations with bean length, bean width and hundred bean weights. Bean length and width showed positive and significant association with each other and with hundred bean weight.

\subsection{Path Coefficient Analysis}

Path coefficient analysis was carried out at genotypic level considering coffee yield per plant as dependent character and yield components as independent characters. Each component has two path action viz., direct effect on coffee yield and indirect effect through components which are not revealed by correlation studies. Genotypic direct and indirect effects of different characters on yield are presented in Table 3.

Path coefficient analysis at genotypic level revealed that number of nodes on primary branches had maximum direct positive effect on coffee yield per tree $(\mathrm{p}=14.853)$ followed by average inter node length of primary branches $(\mathrm{p}=11.740)$, average inter node length of main stem $(\mathrm{p}=2.868)$, angle of primary branches $(\mathrm{p}=1.394)$ and number of primary branches $(\mathrm{p}=1.114)$. Low magnitude and positive direct effects were also exhibited by bean width $(\mathrm{p}=0.869)$, fruit length $((\mathrm{p}=0.779)$ and thickness $(\mathrm{p}=$ $0.429)$, height up to first primary branch $(\mathrm{p}=0.432)$ and stem diameter $(\mathrm{p}=0.234)$ (Table 3$)$.

Among these traits, average inter node length on main stem $(\mathrm{p}=2.868)$, stem diameter $(\mathrm{p}=0.234)$, angle of primary branches $(\mathrm{p}=1.394)$, fruit length $(0.779)$ and thickness $(\mathrm{p}=0.429)$, having positive direct effects on coffee yield per tree, exhibited positive and significant genotypic correlation with coffee yield per tree $(\mathrm{rg}=0.349,0.245,0.245,0.440$ and 0.531 , respectively. Besides, bean width had positive correlation $(\mathrm{rg}=0.138)$ though it is not significant, Indicating the importance of these traits towards the improvement of the coffee yield.

The positive direct effects of average inter node length of main stem, stem diameter, number of nodes of primary branches, number of primary branches and angle of primary branches agree with the findings of Seyoum (2003) and the positive direct effect of canopy diameter on coffee bean yield is similar with the findings of Lemi et al. (2017).

Singh and Chaudhary (1977) expressed their views for cultivated crops in that direct selection should be done in case where correlation coefficients are positive and comparable to the direct effects, whereas indirect selection could be used where correlation coefficients are positive but direct effects are negative or negligible. Therefore, the above six traits, namely, average inter node length on main stem, stem diameter, angle of primary branches, fruit length ,fruit thickness and bean width can be used as selection criteria to improve the coffee bean yield. 
Path coefficient analysis also revealed that average length of primary branches $(\mathrm{p}=-6.669)$, plant height $(\mathrm{p}=-2.066)$, hundred bean weight $(\mathrm{p}=-2.002)$, canopy diameter $(\mathrm{p}=-1.280)$, leaf width $(\mathrm{p}=-$ 1.227), fruit width $(\mathrm{p}=-0.695)$, number of main stem node $(\mathrm{p}=-0.556), \mathrm{CBD}$ severity $(\mathrm{p}=-0.549)$, number of secondary branches $(p=-0.481)$, bean length $(p=-0.326)$ and leaf length $(p=-0.164)$ had negative direct effects on coffee yield per tree.

On the other hand, number of nodes on primary branches $(\mathrm{p}=14.853)$, average inter nodes length of primary branches $(\mathrm{p}=11.740)$, number of primary branches $(\mathrm{P}=1.114)$ and height up to first primary branch $(\mathrm{p}=0.432)$, which had positive direct effect, exhibited negative correlation with coffee yield. The negative correlation they had with coffee yield was mainly due to negative indirect effects via other traits. For instance, the negative correlation of number of nodes on primary branches with coffee yield was due to the negative indirect effect of average inter node length of primary branch, average length primary branches and average internodes length of main stem. Similarly, the negative correlation of average inter node length of primary branches with coffee yield was due to the negative indirect effect of average inter node length of main stem and number of nodes on primary branches. This implies restricted simultaneous selection has to be followed; as restrictions are to be imposed to nullify the undesirable indirect effects in order to make use of the direct effect of these traits. The negative direct effects of plant height, length of primary branches and hundred seed weight in this study is in harmony with the results of Seyoum (2003).

The negative direct effect of canopy diameter and length of primary branch is similar to the report of Ermias (2005). Conversely, the negative direct effect of number of main stem node, number of secondary branches and canopy diameter in the present study contradicts with the findings the same author. This perhaps could be attributed to the differences in the tested materials, environmental conditions and the physiological responses of the crop under the varying agro-ecologies. However, in conformity of this finding, Seyoum (2003) has reported that canopy diameter and number of main stem nodes exerted negative direct effect on four and three years old coffee trees, ,respectively.

Number of main stem nodes, average length of primary branches, and number of secondary branches, canopy diameter, leaf width, and CBD severity had negative direct effects and negative genotypic correlation coefficients. However, of these traits, it is only length of primary branches and CBD severity had negative direct effects and negative and significant genotypic correlation with coffee yield. Therefore, it is evident from these findings that selecting accessions with shorter primary branches and reduced CBD severity level would be effective to improve coffee yield. The residual factor showed that about $90 \%$ of the variation in coffee yield was due to the traits considered in the genotypic path analysis, suggesting that the traits were sufficient to explain the variation in coffee yield.

Table3. Estimates of direct (bold and diagonal) and indirect effects (off diagonal) at genotypic level of 22 traits on yield in 49 coffee germplasm accessions tested at Agaro (2011/12)

\begin{tabular}{|c|c|c|c|c|c|c|c|c|c|c|c|c|c|c|c|c|c|c|c|c|c|c|}
\hline haracter & HUP & TPH & NMS & AILMS & SD & APB & $\overline{\mathrm{NPB}}$ & $\overline{A L P B}$ & NNPB & AILPB & NSB & $\mathrm{CD}$ & $\overline{\mathrm{LL}}$ & $\overline{\mathrm{LW}}$ & $\overline{\mathrm{FL}}$ & FW & FT & $\overline{\mathrm{BL}}$ & BW & HBW & CBD & $\mathrm{rg}$ \\
\hline HUP & 0.432 & -0.891 & -0.036 & 0.853 & 0.093 & 0.742 & 0.315 & -0.013 & -2.653 & 2.565 & -0.065 & 0 & 20 & -0.662 & 0.168 & 0.088 & 0.302 & & 0.134 & 0.569 & 0.055 & $\begin{array}{c}-0.074 \\
-0.074\end{array}$ \\
\hline TPH & 0.186 & -2.066 & -0.311 & 1.891 & 0.132 & 0.856 & 0.372 & -4.384 & -0.527 & 5.398 & -0.299 & -0.609 & -0.066 & -0.655 & 0.255 & 0.000 & 0.072 & -0.00 & 0.086 & -0.498 & 0.230 & 0.061 \\
\hline NNMS & 0.028 & -1.156 & -0.556 & -0.748 & 0.063 & 0.565 & 0.851 & -2.981 & 6.659 & -2.862 & -0.278 & -0.561 & 0.052 & 0.323 & -0.165 & 0.836 & -0.492 & 0.103 & -0.478 & 0.943 & -0.340 & -0.193 \\
\hline AILMS & 0.129 & -1.362 & 0.145 & 2.868 & 0.106 & 0.532 & -0.219 & -2.241 & -6.351 & 8.437 & -0.084 & -0.213 & -0.120 & -1.004 & 0.438 & -0.760 & 0.502 & -0.085 & 0.583 & -1.468 & 0.515 & $0.349^{* 8}$ \\
\hline SD & 0.172 & -1.163 & -0.151 & 1.297 & 0.234 & 0.568 & 0.067 & -2.489 & -0.145 & 3.152 & -0.240 & -0.414 & -0.107 & 0.364 & 0.093 & 0.051 & 0.085 & -0.029 & 0.229 & -0.629 & 0.006 & $0.245^{* 8}$ \\
\hline APB & 0.230 & -1.268 & -0.225 & 1.095 & 0.095 & 1.394 & 0.127 & 1.312 & -7.637 & 5.237 & -0.147 & 0.451 & -0.079 & -0.367 & 0.076 & 0.148 & 0.005 & 0.030 & -0.012 & -0.069 & -0.171 & $0.245^{* 8}$ \\
\hline NPB & -0.122 & -0.689 & -0.424 & -0.564 & 0.014 & 0.159 & 1.114 & -3.804 & 9.105 & -4.576 & -0.416 & -0.641 & 0.037 & 0.271 & & 0.594 & -0.415 & 0.039 & -0.422 & 0.702 & -0.107 & $-0.323^{* *}$ \\
\hline ALPB & 0.001 & -1.358 & -0.248 & 0.964 & 0.087 & -0.274 & 0.635 & -6.669 & 7.416 & 0.720 & -0.185 & -1.495 & 0.010 & -0.168 & 0.122 & -0.186 & 0.109 & -0.005 & 0.024 & -0.413 & 0.534 & $-0.379^{* 8}$ \\
\hline NNPB & -0.077 & 0.073 & -0.249 & -1.226 & -0.002 & -0.717 & 0.683 & -3.330 & 14.853 & -9.780 & -0.081 & -0.824 & 0.083 & 0.431 & -0.304 & 0.398 & -0.264 & 0.042 & -0.278 & 0.469 & -0.115 & -0.217 \\
\hline AILPB & 0.094 & -0.950 & 0.135 & 2.061 & 0.063 & 0.622 & -0.434 & -0.409 & -12.373 & 11.740 & 0.001 & -0.029 & -0.088 & -0.619 & 0.439 & -0.594 & 0.371 & -0.045 & 0.318 & -0.797 & 0.492 & -0.003 \\
\hline NSB & 0.059 & -1.284 & -0.321 & 0.500 & 0.116 & 0.425 & 0.963 & -2.566 & 2.498 & -0.025 & -0.481 & -0.345 & 0.045 & 0.071 & 0.100 & 0.307 & -0.139 & -0.058 & -0.222 & -0.009 & 0.242 & -0.125 \\
\hline $\mathrm{CD}$ & 0.022 & -0.983 & -0.244 & 0.478 & 0.076 & -0.491 & 0.558 & -7.789 & 9.564 & 0.266 & -0.130 & -1.280 & -0.040 & -0.459 & 0.017 & -0.131 & 0.158 & 0.045 & -0.061 & 0.005 & 0.284 & -0.132 \\
\hline LL & 0.117 & -0.829 & 0.175 & 2.102 & 0.152 & 0.667 & -0.254 & 0.420 & -7.522 & 6.258 & 0.131 & -0.314 & -0.164 & -0.623 & 0.213 & -0.675 & 0.222 & -0.037 & 0.280 & -0.884 & 0.356 & -0.209 \\
\hline LW & 0.233 & -1.104 & 0.146 & 2.346 & 0.069 & 0.417 & -0.246 & -0.911 & -5.222 & 5.925 & 0.028 & -0.478 & -0.083 & -1.227 & 0.153 & -0.396 & 0.246 & -0.018 & 0.406 & -0.921 & 0.578 & 0.059 \\
\hline FL & 0.093 & -0.676 & 0.118 & 1.614 & 0.028 & 0.136 & -0.253 & -1.044 & -5.807 & 6.620 & -0.062 & -0.029 & -0.045 & -0.241 & 0.779 & -0.088 & 0.186 & -0.329 & 0.584 & -1.582 & 0.437 & $0.440^{88}$ \\
\hline FW & 0.055 & 0.000 & 0.669 & 3.136 & -0.017 & -0.297 & -0.952 & -1.790 & -8.515 & 10.046 & 0.212 & -0.242 & -0.160 & -0.699 & 0.098 & -0.695 & 0.249 & -0.187 & 0.746 & -1.960 & 0.557 & $0.253^{8 *}$ \\
\hline FT & 0.305 & -0.347 & 0.638 & 3.359 & 0.046 & 0.016 & -1.079 & -1.694 & -9.147 & 10.156 & 0.156 & -0.473 & -0.085 & -0.705 & 0.339 & -0.403 & 0.429 & -0.310 & 1.024 & -2.124 & 0.432 & $0.531^{* *}$ \\
\hline $\mathrm{BL}$ & 0.021 & -0.005 & 0.176 & 0.747 & 0.021 & -0.127 & -0.133 & -0.096 & -1.898 & 1.639 & -0.086 & 0.178 & -0.019 & -0.068 & 0.787 & -0.399 & 0.408 & -0.326 & 0.545 & -1.513 & 0223 & 0.075 \\
\hline BW & 0.067 & -0.205 & 0.306 & 1.925 & 0.062 & -0.019 & -0.541 & -0.185 & -4.761 & 4.298 & 0.123 & 0.089 & -0.053 & -0.573 & 0.523 & -0.596 & 0.505 & -0.205 & 0.869 & -1.797 & 0.306 & 0.138 \\
\hline HBW & 0.123 & -0.514 & 0.262 & 2.103 & 0.073 & 0.048 & -0.391 & -1.377 & -3.478 & 4.673 & -0.002 & 0.003 & -0.073 & -0.564 & 0.615 & -0.680 & 0.455 & -0.246 & 0.780 & -2.002 & 0.298 & 0.106 \\
\hline CBD & -0.043 & 0.865 & -0.344 & -2.694 & -0.003 & 0.435 & 0.216 & 6.497 & 3.117 & -10.517 & 0.212 & 0.663 & 0.106 & 1.292 & -0.621 & \begin{tabular}{|l|}
0.705 \\
\end{tabular} & -0.337 & 0.132 & -0.485 & 1.086 & -0.549 & $-0.265^{*}$ \\
\hline
\end{tabular}

Residual effects $=0.100$

$H U P=$ height up to first primary branches. TPH= total plant height, NMSN= number of main stem nodes, AILMS= average inter nodes length on main stem, $S D=$ stem diameter, $A P B=$ Angle of primary branches, $N P B=$ number of primary branches, ALPB= Average length of primary branches, $N N P B=$ number of nodes on primary branches, $A I L P B=$ average inter nodes length on primary branches, NSB=Number of secondary branches, $C D=$ stem diameter, $L L=$ leaf length, $L W=$ leaf width, $F L=$ fruit length, $F W=$ fruit width, $F T=$ fruit thickness, $B L=$ bean length, $B W=$ bean width, $H B W=$ hundred bean weights, $C B D=$ coffee berry disease, $Y D /$ tr $=y i e l d$ 


\section{SUMMARY AND CONCLUSION}

Information on the relationship between coffee yield and its components is important for selecting two or more variables contributing to yield. All yield related traits showed non significant phenotypic correlation with coffee yield. However, average inter node length on stem, stem diameter, angle of primary branches, number of primary branches, average length of primary branches, fruit length, fruit width and fruit thickness showed positive and significant genotypic correlation with coffee yield and are important components to improve coffee yield. Besides, most of yield components had significant genotypic correlations among each other, suggesting the possibility of simultaneous improvement these traits. The path coefficient analysis indicated that characters like average inter node length on main stem, stem diameter, angle of primary branches, fruit length, fruit thickness and bean width should be considered for selecting high yielding genotypes. So, in the process of selection much attention should be given to these traits as they are helpful for selection to improve coffee yield.

\section{ACKNOWLEDGEMENTS}

The author would like to acknowledge Ethiopian Institute of Agricultural research for allocating required budget for research. I am also grateful to jimma and Agaro Agricultural Research Centers for facilitating the work and finally I extend my sincere gratitude to Teshome Bushira, Mebrate Kidane, Seleshi Tesfaye, Admasu Haile, Matiwos Shigute and Mergiya Ayalew for their unreserved support in field data collection.

\section{REFERENCES}

[1] Ariyo,O.J., M.E., Akeriova and C.A. Fatokun, 1987. Plant character correlation and path analysis of pod yield in Okra (Abelmoschus esculentus). Euphytica 36: 677-686.

[2] Cilas, C., P.Bouharmont, M, Boccara, A.B. Eskes and P.H. Boradat, 1998. Prediction of genetic value for coffee production in Coffea arabica from a half diallel with lines and hybrids. Euphytica, 104:49-59

[3] Dewey, D.R. and K.H. Lu, 1959. A correlation and path coefficient analysis of components of crested wheat grass seed production. Agronomy Journal, 51:515-518

[4] Endale Taye, Taye Kufa, Antenhe Nestre, Tesfaye Shimber, Alemseged Yilma and Tesfaye Ayano, 2008. Research on coffee field management.pp.187-195. In: Girma Adugna, Bayetta Belachew, Tesfaye Shimber, Endale Taye and Taye Kufa (eds.). Coffee Diversity and Knowledge. Proceedings of a National Workshop Four Decades of Coffee Research and Development in Ethiopia, 14-17 August 2007, Addis Ababa, Ethiopia

[5] Elias A. 2005. Economics of coffee bean marketing. a case studies of Gomma wereda in Jimma zone of Ethiopia. An M.Sc thesis submitted to school of graduate studies of Haromaya University, Haromaya

[6] Ermias Habte. 2005. Evaluation of Wollega coffee germplasm for yield, yield component and resistant to coffee berry disease at early bearing stage. An MSc thesis submitted to school of graduate studies of Alemaya University. 69p.

[7] Falconer.D.S.1989.Introduction to Quantitative Genetics. Longman Scientific and Technical.Jhony Wiley and Sons, Inc. Newyork. 438p

[8] Federal Democratic Republic of Ethiopia Ministry of Trade (FDRE MOT). 2012. Coffee Opportunities in Ethiopia, Addis Ababa Ethiopia

[9] Food and Agricultural organization (FAO). 2009. Study prepared in the framework of FAO project GCP/RAF/404/GER.The Market for Organic and Fair-Trade coffee."Increasing income and food security of small farmers in West and Central Africa through exports of organic and fair-trade tropical products." September, 2009.

[10] Gizachew Atinafu and Hussein Mohammed.2017. Association and path coefficient analysis of yield and yield attributes of coffee (Coffea arabica L.) under Sidama specialty coffee growing area, Awada, southern Ethiopia. Adv Crop Sci Tech 5: 307.

[11] Gole, T.W. and Senebeta, F., 2008. Sustainable and promotion of forest coffee in Bale, Ethiopia. Bale EcoRegion Sustainable Management Programme SOS Sahel/F ARM-Africa, Addis Ababa.

[12] International coffee organization (ICO).2011.The story of coffee.

[13] International Plant Genetic Resource Institute (IPGRI). 1996. Diversity for development. Rome, International Plant Genetic Resources Institute

[14] Johnson, H.W.,H.F., Robinson, R.F and Comstock.1955. Estimates of genetic and environmental variability in soya bean agronomy, J. 47: 314-318. 
[15] Lemi Beksisa, Ashenafi Ayano and Tadesse Benti. 2017. Correlation and path coefficient analysis for yield and yield components in some Ethiopian accessions of Arabica Coffee. International Journal of Plant Breeding and Crop Science, 4(2):178-18

[16] Leroy T., Montgnon C.,Cilas C., Yapo A.,Charmetant, P. and Eskes, A.B. 1997. Reciprocal recurrent selection applied to coffee canephora Pierre. Genetic gains and results of first cycle in intergroup crosses. Euphytica, 95(3): 337-354

[17] Montagnon C., Flori A. and Cilas C. 2001. A new method to asses competition in coffee clonal trials with single tree plots in Coted'Ivoire. Argon. J. 93:227-231

[18] Olika Kitila, Sentayehu Alamerew, Taye Kufa and Woyessa Garedew. 2011. Genetic diversity analysis of Limmu coffee (Coffea arabica L.) collection using quantitative traits in Ethiopia. International Journal of Agricultural Research, 6(6):470-481.

[19] Prakash, N.S., Combes, M.C., Somanna, N. and Lashermes, P. 2002. AFLP analysis of introgression in coffee cultivars (Coffea arabica L.) derived from a natural interspecific hybrid. Euphytica, 124(3):.265-271.

[20] Steiger DL, Nagai C, Moore PH, Morden CW, Osgood RW, Ming R (2002). AFLP analysis of genetic diversity within and among Coffea arabica cultivars. Theoretical and Applied Genetics 105: 209-215.

[21] Rangaswamy, R. 1995. A Text Book of Agricultural Statistics: Wiley Eastern Limited, New Delhi, India, $496 \mathrm{p}$.

[22] SAS, 2008. Statistical analysis system (version 9.2), SAS Institute, Cary, NC.USA

[23] Seyoum Seifu. 2003. genetic divergence for seedling parameters and associations among agronomic traits in the Ethiopian coffee (Coffea arabica L.) germplasm (M.Sc thesis, school of graduate studies of Alemaya University).

[24] Singh,.R.K. and B.D. Chaudhary, 1987. Biometrical methods in quantitative genetic analysis. Kalyani publishers, New Delhi-Ludhiana, India. 318p.

[25] Zebene Mikru and Wondwosen Tena, 2008. Potential and constraints of Nitosol and Acrisols.pp. 209-216. In: Girma Adugna, Bayetta Belachew, Tesfaye Shimber, Endale Taye and Taye Kufa (eds.).Coffee diversity and knowledge. Proceedings of a national workshop four decades of coffee research and development in Ethiopia, 14-17 August 2007, Addis Ababa, Ethiopia.

Citation: Getachew WeldeMichael, (2019). "Character Association and Path Coefficient Analysis for Yield and Its Related Traits in Ethiopian Coffee (Coffea arabica L.) Accessions" International Journal of Research Studies in Agricultural Sciences (IJRSAS), 5(3), pp. 19-29, http://dx.doi.org/10.20431/2454-6224.0503003

Copyright: (C) 2019 Authors. This is an open-access article distributed under the terms of the Creative Commons Attribution License, which permits unrestricted use, distribution, and reproduction in any medium, provided the original author and source are credited. 